\title{
Imperfect retention of natural bacterioplankton cells by glass fiber filters
}

\author{
SangHoon Lee ${ }^{1}$, Young-Chul Kang ${ }^{1}$, Jed A. Fuhrman ${ }^{2}$ \\ ${ }^{1}$ Polar Research Center, Korea Ocean Research \& Development Institute, Ansan, PO Box 29, Seoul 425-600, Korea \\ ${ }^{2}$ Department of Biological Sciences, University of Southern California, Los Angeles, California 90089-0371, USA
}

\begin{abstract}
Glass fiber filters are widely used to concentrate and collect a variety of particles suspended in seawater. The filters are particularly useful for chemical analyses of the filter-retained particles, because of the physico-chemical stability of the material the filters are made of. Despite this usefulness, very small particles, e.g. many planktonic bacteria, are known to pass the glass fiber filters, and little information is currently available on the fraction passing the filters. In this study, natural bacterioplankton cells were filtered through Whatman GF/F filters, and apparent cell size-frequency distributions were obtained by epifluorescence photomicrography before and after the filtration. Seawater samples were from a northwest Atlantic coast and an Antarctic sea. Filtrate contained 35 to $43 \%$ of the total bacterial cell count, equivalent to 22 to $38 \%$ of the total bacterial biomass. Size-frequency distributions showed that cells larger than $0.8 \mu \mathrm{m}$ diameter (volume-equivalent spherical diameter, VESD) did not pass the filters, however the filters retained substantial numbers of small (VESD $<0.8 \mu \mathrm{m}$ ) bacteria. In comparisons of the different types of glass fiber filters, retention efficiency (fraction of the cells retained by a filter) ranged from ca 13 to $51 \%$, i.e. 49 to $87 \%$ of the natural bacterioplankton cells passed through the tested filters. Interpretations of data obtained via filtrations through glass fiber filters must properly consider the fraction not retained by the filters.
\end{abstract}

KEY WORDS: Bacterioplankton $\cdot$ GF/F filtration $\cdot$ Retention efficiency $\cdot$ Size distribution $\cdot$ Particulate organic matter

\section{INTRODUCTION}

Particles suspended in seawater often need to be concentrated prior to an analysis, because the particles are present in a very diluted form. Filtration is one of the most commonly used methods for concentration, and glass fiber filters are widely used because of chemical inertness and non-interference of the filter material (glass fiber) for chemical assays. In addition, the matrix structure of the glass fibers provides a large filtering capacity, i.e. fast filtration and less clogging. These features of glass fiber filters are of particular advantage for the collection and chemical assays of suspended particles such as particulate organic matter (Griffith et al. 1990, Malone \& Ducklow 1990, Hecky et al. 1993), photosynthetic pigments (Bricaud \& Stramski 1990, Joint \& Pomroy 1993), or bacteria (Nagata 1986, Lee \& Fuhrman 1987). Glass fiber filters are also used in order to remove particles from liquid for the subsequent analy- sis of the dissolved materials in the liquid (Nagata \& Watanabe 1990).

However, submicron-size particles are known to pass glass fiber filters (Nagata 1986, Lee \& Fuhrman 1987, Taguchi \& Laws 1988, Stramski 1990), and Nagata (1986) reported that different types of glass fiber filters (e.g. Whatman GF/C and GF/F) retain particles with different retention efficiencies (fraction of the cells retained by a filter). Nevertheless, little is known about the exact particle-retention properties of the glass fiber filters. In a study using natural marine planktonic bacteria cultured in filter-sterilized unsupplemented seawater, Lee \& Fuhrman (1987) reported that about $47 \%$ of bacterial cells passed Whatman GF/ $F$ filters. These retention efficiency values, although not from truly natural cells, were remotely cited for field studies (e.g. Malone \& Ducklow 1990). Field samples, i.e. natural bacteria, may have sizefrequency distributions that are different from those of the cultures. 
It is currently unclear whether glass fiber filters retain submicron particles simply by random trapping, or the filters positively retain particles larger than a certain size class, and if so, at what size the filters cut off. Understanding of the particle-retention properties of filters will help assess the extent of possible errors caused by imperfect retention. For instance, a size-frequency distribution of the particles that pass a glass fiber filter will be directly linked to the quantity obtained via either concentration or removal by the filter.

Loss of bacteria or bacteria-sized particles by glass fiber filters may become a substantial error factor, depending on the circumstances, i.e. what is being measured or where the samples are from. For example, submicron particles that pass glass fiber filters will produce a relatively large error for a sample from oligotrophic oceanic water, where bacterial biomass contributes a significant portion of the total particulate organic carbon (Cho \& Azam 1988, Fuhrman et al. 1989). Besides, bacterial cells contain relatively high nitrogen content (i.e. low cellular C:N ratio; Lee \& Fuhrman 1987) as compared to those of algal cells or detritus. Therefore, imperfect retention of bacteria may result in a differential change of the chemical species, and thus care must be taken in measuring chemical compositions or $\mathrm{C}: \mathrm{N}$ ratios of either the collected particles or the seemingly particle-free liquid.

In this study, natural seawater samples were filtered through Whatman GF/F glass fiber filters, and sizefrequency distributions of the bacterial cells were obtained by epifluorescence photomicrography before and after filtration. GF/F filtrate contained ca $40 \%$ of the bacterial cells. This was equivalent to about $1 / 3$ of the bacterial biomass. Interestingly, cells of $\leq 0.8 \mu \mathrm{m}$ diameter (volume-equivalent spherical diameter, VESD) were present in both the filtrate and the fraction retained by the filter. Depending on the filter type, 49 to $87 \%$ of the cells passed the glass fiber filters. Proper application of glass fiber filters requires the selection of a correct filter type and calibration for the submicron particles passing the filters.

\section{MATERIALS AND METHODS}

Seawater samples (see Table 1) were collected at a beach in Long Island, New York, USA, from the surface (depth $<0.5 \mathrm{~m}$ ) with a bucket (Long Island Sound samples: LIS), and from surface waters (depth $<10 \mathrm{~m}$ ) near Livingston Island, Antarctica, with Niskin bottles (Antarctic samples: ANT). A volume of $1 \mathrm{l}$ of the collected seawater was immediately (in $<1$ h) filtered through a Whatman GF/F glass fiber filter $(25 \mathrm{~mm}$ diameter) with a vacuum pressure $<16 \mathrm{kPa}(12 \mathrm{~cm} \mathrm{Hg})$. After filtration, subsamples of the unfiltered whole sea- water and the GF/F filtrate were preserved with buffered formalin ( $\mathrm{V} / \mathrm{V}$ ratio $5 \%$ ), and stored at $4^{\circ} \mathrm{C}$ in the dark until the preparation of microscope slides (in $<24$ h). Bacterial cells were stained with acridine orange (AO) and filtered on Irgalan black-stained $0.2 \mu \mathrm{m}$ pore-size Nuclepore (Costar, Cambridge, MA, USA) filters (Hobbie et al. 1977).

For the test of retention efficiencies of different filter types from Whatman and Gelman (Ann Arbor, MI, USA), $100 \mathrm{ml}$ of the LIS2 sample was filtered through the glass fiber filters listed in Table 2, and subsamples from the filtrate of each filter type were prepared as described above. Filtrations through a filter type were repeated 3 to 5 times for the replicate measurement. AO microscope slides were made with the subsamples as described above.

Cell abundances of the whole seawater and the filtrate were determined by the $A O$ direct count (DC) method (Hobbie et al. 1977). Cell size was measured via $\mathrm{AO}$ epifluorescence photomicrography. A Zeiss Axiophot with an HBO 50 mercury lamp or an Olympus $\mathrm{BH}$ with an HBO 100 mercury lamp was used. AO photomicrography and the size measurements were previously described in detail by Lee \& Fuhrman (1987). In brief, fluorescent cell images were photographed on Kodak Ektachrome ASA 400 films, and projected onto a screen (final magnification $\times 10^{4}$ ). Cells were categorized as spheres, if the lengths of 2 perpendicular axes of a cell image differed by $\leq 0.1 \mu m$; otherwise, they were classified as rods (a cylinder with 2 spherical ends). Cell dimensions of the projected images were measured to $1 \mathrm{~mm}$ ( $1 \mathrm{~mm}$ of the projected image $=0.1 \mu \mathrm{m}$ of the original scale). We routinely used photographic slides of a stage micrometer (10 $\mu \mathrm{m}$ spacing) and single-size $(0.7 \mu \mathrm{m}$ diameter $)$ fluorescent standard beads for the projector setup and calibrations for size measurements. A total of 300 to 700 bacterial cells were measured from each subsample, and cell volumes (biovolumes) were calculated from the measured linear dimensions assuming either a sphere or a sphere-capped cylinder.

Mean cell volume (Table 1) was determined by dividing the sum of the individual cell volumes by the number of cells measured. Total biovolume in 11 (Table 1) was calculated by multiplying the mean cell volume by the total cell number in $1 \mathrm{l}$. Total bacterial biomass in 1 l (Table 1) was estimated from the total biovolume in $1 \mathrm{I}$, using the biovolume-to-biomass conversion factors $\left(0.38 \mathrm{~g}\right.$ carbon $\mathrm{cm}^{-3}, 0.10 \mathrm{~g}$ nitrogen $\mathrm{cm}^{-3}$; Lee \& Fuhrman 1987).

The size-frequency distribution of a measured population (300 to 700 cells) was proportionately scaled up to the total bacterial cell count in $1 \mathrm{l}$ (Fig. 1). The biovolumes of the individual cells in a size class were summed, and cumulatively added to the total biovol- 


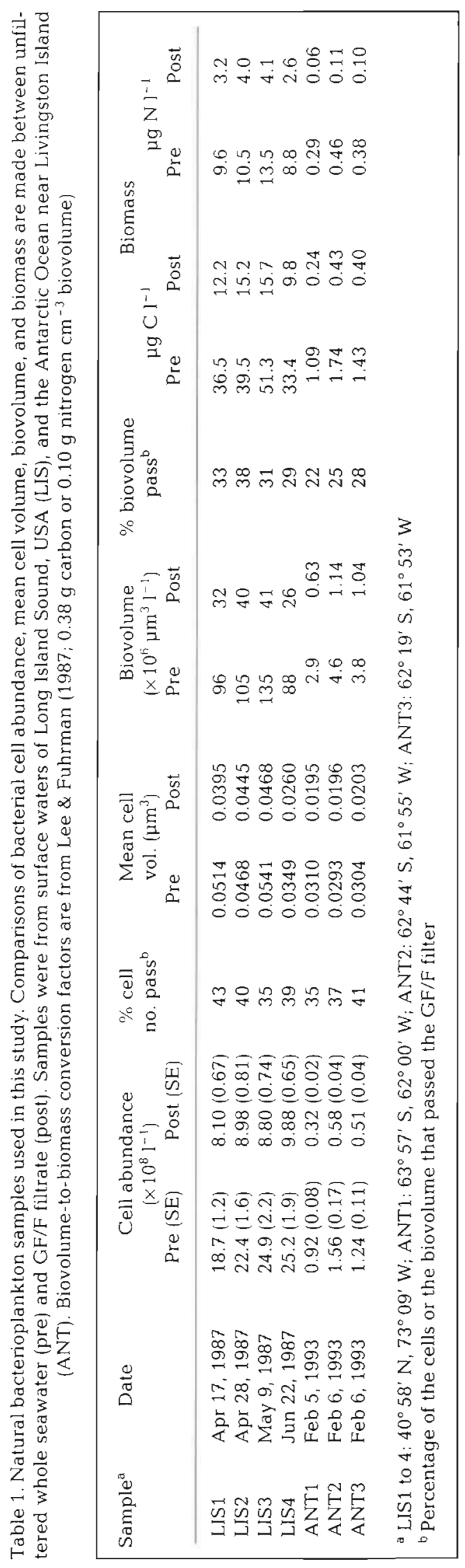

ume of the next size class in order to produce the cumulative biovolume data presented in Fig. 2. Size class of the frequency distributions is presented as VESD.

\section{RESULTS AND DISCUSSION}

The fraction of the cells passing GF/F filters was 35 to $43 \%$ (mean $=39 \%)$ of the total cell count (Table 1$)$. These numbers are lower by $8 \%$ than those reported by Lee $\&$ Fuhrman $(1987$ : mean $=47 \%$, range $=35$ to $57 \%$ ). In their study, natural planktonic bacteria that passed $0.6 \mu \mathrm{m}$ pore-size Nuclepore filters were diluted and cultured in filter-sterilized particle-free unsupplemented natural seawater prepared with type GS Millipore (Bedford, MA) filters. Eliminations of the cells $>0.6 \mu \mathrm{m}$ and the dilution culturing may have lowered the frequencies of the cells at both extreme ends of the size range, i.e. very small or very large cells. Mean cell volumes of the naturally derived and cultured cells $\left(0.032\right.$ to $0.062 \mu^{3}$; Lee \& Fuhrman 1987) are almost comparable to those of the natural cells reported in this study $\left(0.0293\right.$ to $\left.0.0541 \mu^{3}\right)$. Without an apparent difference of the mean cell size, predominance of the cells of mid-range size (and accordingly fewer cells of both the extreme sizes) could result in the increase in cells passing the filter. Another possible explanation for the higher retention found in the current study is the presence of particle-associated cells in natural seawater. However, particle-associated cells in the seawater samples of this study were only ca $5 \%$ of the total cell count.

Glass fiber filters are usually precombusted for measurements of particulate organic matter. Glass fiber filters used in this study were not precombusted, while Lee \& Fuhrman (1987) used precombusted filters. Precombustion may change the filter's retention efficiency by affecting the texture of the filters. This needs further investigation.

The fraction of the cells passing GF/F filters in Table 1 is lower by $10 \%$ than that shown in Table 2 . Clogging of the filters with the filter-retained particles

Table 2. Percentage of natural bacterioplankton cells passing various types of glass fiber filters. Each filter was tested with $100 \mathrm{ml}$ of the seawater sample LIS2 (see Table 1). n: number of replicates

\begin{tabular}{|lcr|}
\hline \multirow{2}{*}{ Filter type } & \multicolumn{2}{c|}{ Percent passing } \\
& Mean & SD (n) \\
\hline Whatman GF/F & 49 & $7(3)$ \\
Whatman QM-A & 71 & $12(3)$ \\
Whatman 934-AH & 80 & $9(4)$ \\
Gelman A/E & 87 & $6(5)$ \\
\hline
\end{tabular}



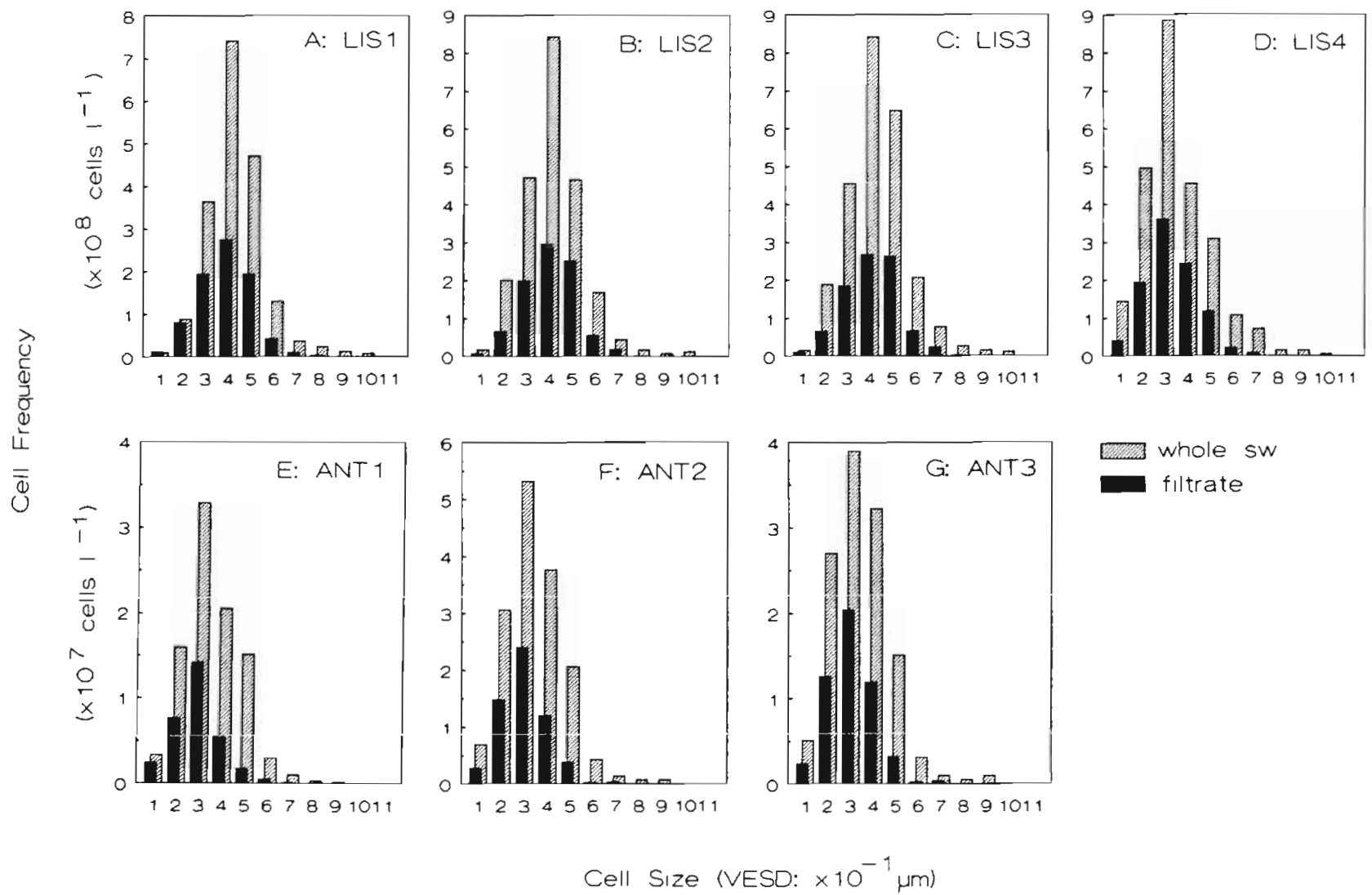

Cell SIze (VESO: $\times 10^{-1} \mathrm{um}$ )

Fig. 1. Size-frequency distributions of natural planktonic bacterial cells before and after filtration through GF/F filter. Whole seawater (shaded bars) and filtrate (solid bars) denote before and after filtration, respectively. Cell size is presented as volumeequivalent spherical diameter (VESD). See Table 1 for the sample names in each panel

would probably affect the retention efficiency; as the filters become clogged, particle trapping would become more efficient. We speculate this may partially explain the higher retention in Table $1(1000 \mathrm{ml}$ filtered), as compared to that of Table $2(100 \mathrm{ml}$ filtered). Besides, we observed occasional release of the onceretained particles from glass fiber filters, when filtering large volumes (liters) of seawater. We suggest that subsamples for the determination of the particle abundance in the filtrate should be from the entire filtrate at the end of the filtration.

Cells in the filtrate were apparently in the size class 0.1 to $0.8 \mu \mathrm{m}$ VESD, while the unfiltered whole seawater contained larger cells (0.9 to $1.1 \mu \mathrm{m}$ VESD; Fig. 1). Cells $>0.8 \mu \mathrm{m}$ VESD were not found in the filtrates, however substantial numbers of small cells in the 0.1 to $0.8 \mu \mathrm{m}$ range were present in both the filter-retained fraction and the filtrate (Fig. 1 ; retained portion = shaded bar - solid bar). Separation of the small cells ( $<0.8 \mu \mathrm{m}$ VESD) by GF/F filters seems to be more by chance than by size-dependent segregation. Unlike the membrane filters that have relatively strict pore size, glass fiber filters seem to have a vague cutoff size due to the loose glass fiber matrix. As a result, size distributions of the filter-passed population and the retained one (shaded - solid bars) are similar instead of having 2 separate modes (Fig. 1).

Different types of glass fiber filters showed different retention efficiencies in filtering the bacteria-size particles (Table 2). GF/F filters showed the highest retention efficiency, while Gelman type $\mathrm{A} / \mathrm{E}$ was the least efficient among the tested filters (Table 2). However, $\mathrm{GF} / \mathrm{F}$ is the only one significantly different from the other types $(p=0.05)$. It is currently unclear at what size (i.e. VESD) the tested filters would cut off, and whether the filters would have the same retention properties discussed above. One needs to choose a correct filter type, depending on the purpose of the filtration.

The fraction of the biovolume passing GF/F filters ranged from 22 to $38 \%$ (mean $=29 \%$ ), lower than the fraction of the cells passing the filters (mean $=39 \%$; Table 1). This is because the mean cell volume of the cells passing the filters is smaller than that of the cells in the unfiltered whole seawater (Table 1). Fig. 1 also shows that the size-frequency distributions of the fil- 

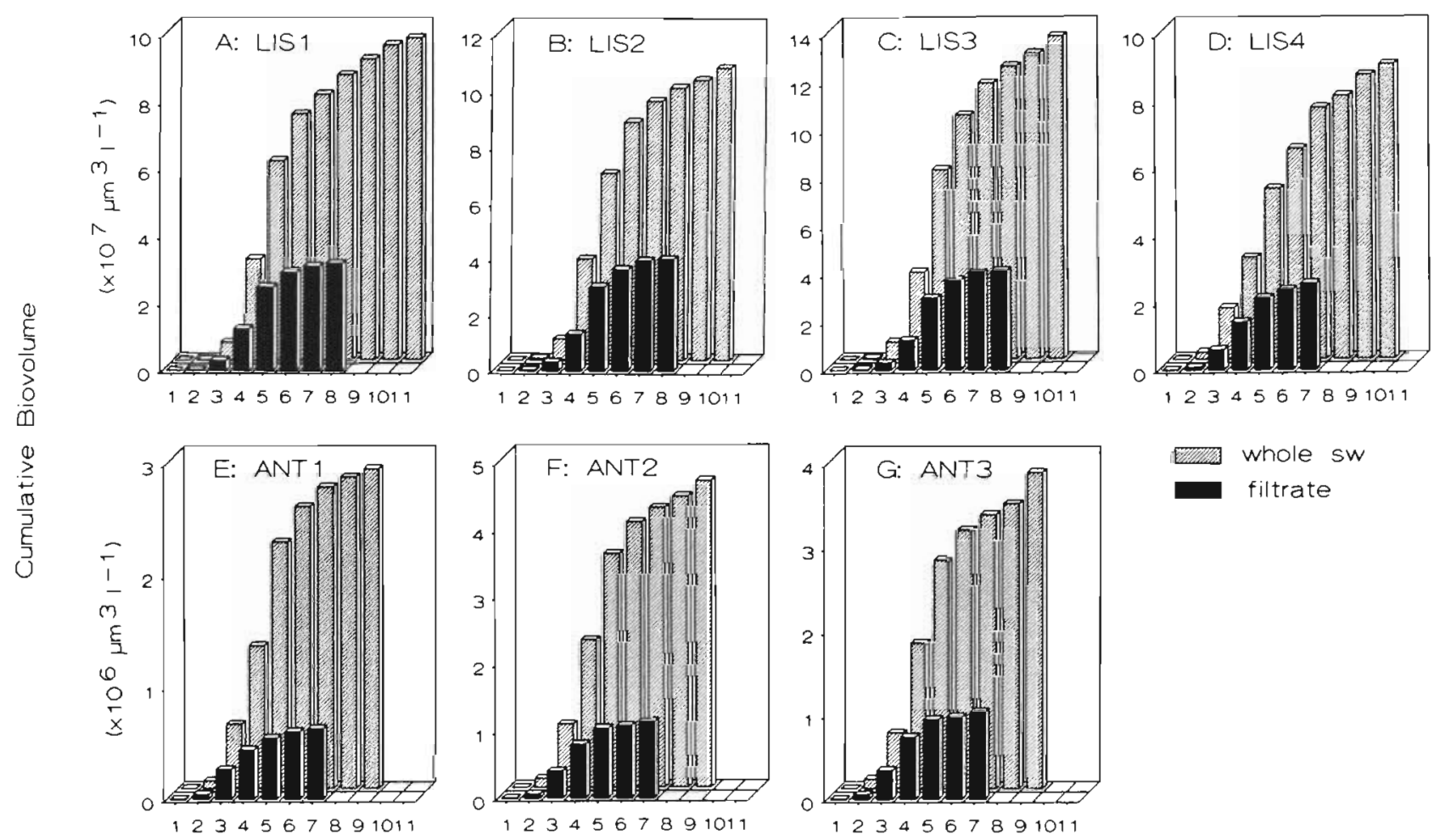

$$
\text { Cell SIze (VESO: } \left.\times 10^{-1} \mu \mathrm{m}\right)
$$

Fig. 2. Cumulative biovolume over the range of cell sizes measured before (shaded bars) and after (solid bars) the filtration through GF/F filter. See Table 1 for the sample names in each panel

trates are skewed to smaller size classes, as compared to the distributions of the unfiltered whole seawater.

Most of the biovolume (and thus, biomass) in filtered or unfiltered seawater was contributed by the mediumsize cells, as shown by a sharp increase of the cumulative biovolumes mostly over the range of 0.3 to $0.5 \mu \mathrm{m}$ VESD (Fig. 2). In natural seawater, a few large cells did sometimes contribute substantially to the total biovolume (e.g. Fig. 2G), but their contribution was restricted in general by their low abundance. The relative abundance of small cells in the 0.1 to $0.2 \mu \mathrm{m}$ range is higher in some samples (Fig. 1D to $\mathrm{G}$ ) than in others (Fig. 1A to C). Despite the abundance, these small cells contributed little to the total biovolume; no difference in the pattern of increase was observed between Fig. 2A to $\mathrm{C}$ and Fig. 2D to $\mathrm{G}$ in the 0.1 to $0.2 \mu \mathrm{m}$ range.

Antarctic (ANT) samples showed relatively small mean cell size compared to temperate coastal (LIS) samples (Table 1). However, there was no significant correlation between mean cell size and retention efficiency, i.e. large mean cell size did not necessarily lead to a higher retention of the cells. The lack of a significant correlation between the 2 parameters indirectly supports the previous speculation that cells in the medium-size range may play a major role in determining both the population's mean cell size and the fraction passing the filter. Note that these medium-size cells are the group contributing most to the bacterial biovolume (and thus, biomass), as shown by the rapid increase of the cumulative biovolume in the 0.3 to $0.5 \mu \mathrm{m}$ range (Fig. 2).

Bacterial biomass that passes a filter is the loss term, if one intends to measure a parameter from the collected particles (e.g. Malone \& Ducklow 1990). In the current study, for instance, the imperfect retention by the GF/F filters would have resulted in an underestimation of bacterial biomass by ca $30 \%$. In order to measure dissolved entities, particles are often removed by GF/F filters (e.g. Nagata \& Watanabe 1990). Depending on the analytical method, particles that pass a GF/F filter will contribute to some extent to the quantity measured from the GF/Ffiltered liquid. The relative magnitude of the error due to imperfect retention may become smaller or even negligible if other biological particles, e.g. phytoplankton cells, are counted in together. However, in an oligotrophic ecosystem where most of the water-column bio- 
mass is from bacterioplankton (Cho \& Azam 1988, Fuhrman et al. 1989), this error may not be trivial at all. Bacterial cells contain relatively high nitrogen content (carbon to nitrogen ratio $=3.7$; Lee \& Fuhrman 1987), and, for instance, the nitrogen contributed by the filterpassing bacterial cells ranges from 0.06 to $4.1 \mu \mathrm{g} \mathrm{l^{-1 }}$ (Table 1). This is equivalent to ca 4 to $290 \mathrm{nM}$ nitrogen. Selective loss (or addition) of the nitrogen-rich bacterial cells due to imperfect retention could also affect C:N ratios obtained with $\mathrm{GF} / \mathrm{F}$ filtrations.

Size measurement of natural planktonic bacteria has been questioned by many with regard to the reliability of the method involved (e.g. Joint \& Pomroy 1987, Suzuki et al. 1993). Major concerns are directed to the discrepancies among the results obtained via different techniques (Psenner 1990). Intercomparisons among operators and methods have been attempted by a group of scientists; differences were mostly due to the different sizing criteria (M. Sieracki pers. comm.). However, strictly following a set of criteria should make the results internally consistent within studies. Lee \& Fuhrman (1987) used the same sizing technique and criteria as we used in this study, and reported an underestimation of linear dimensions by ca $8 \%$. Data presented in the current study were not corrected for the potential error. Cell size and biovolume may have been underestimated in this study. However, sizing error would not affect the percentages of the cells or the biovolume that passed the filters.

Bacterioplankton from different marine environments may show different filter-retention efficiencies or sizefrequency distributions. In this study, we used seawater samples from a temperate coast and an Antarctic sea. Despite the geographical and climatological differences, no outstanding differences were observed between the 2 locations in the filter-retention efficiencies and the size-frequency distribution patterns.

This study demonstrated how much of natural bacterial cells and biovolume could be passing GF/F filters. Retention properties of GF/F filters were analyzed via comparisons of the size-frequency distributions of the bacterial cells before and after filtration. GF/F filters, the most efficient among the tested glass fiber filters, retained only about $2 / 3$ of the bacterial biomass. In interpreting data obtained with glass fiber filters, attention should be paid to the loss or the extra gain due to imperfect retention. Definitions of what constitutes dissolved or particulate matter could vary depending on the nature of a study, however a functional group of organisms should not be divided into 2 groups, dissolved or particulate, as a result of the definition.

This article was presented by B.\& E. Sherr (Senior Editorial Advisors), Corvallis, Oregon, USA
Acknowledgements. This research was supported by Korea Ministry of Science \& Technology Contract KORDI-PE-00426. and in part by U.S. National Science Foundation grant OCE8410074 .

\section{LITERATURE CITED}

Bricaud, A., Stramski, D. (1990). Spectral absorption coefficients of living phytoplankton and nonalgal biogenous matter: a comparison between the Peru upwelling area and Sargasso Sea. Limnol. Oceanogr. 35: 562-582

Cho, B. C., Azam, F. (1988). Major role of bacteria in biogeochemical fluxes in the ocean's interior. Nature 332: $441-443$

Fuhrman, J. A., Sleeter, T D., Carlson, C. A., Proctor, L. M. (1989). Dominance of bacterial biomass in the Sargasso Sea and its ecological implications. Mar. Ecol. Prog. Ser. 57: $207-217$

Griffith, P. C., Douglas, D. J., Wainright, S. C. (1990). Metabolic activity of size-fractionated microbial plankton in estuarine, nearshore, and continental shelf waters of Georgia. Mar. Ecol. Prog. Ser. 59: 263-270

Hecky, R. E., Campbell, P., Hendzel, L. L. (1993). The stoichiometry of carbon, nitrogen, and phosphorus in particulate matter of lakes and oceans. Limnol. Oceanogr. 38: $709-724$

Hobbie, J. E., Daley, R. J., Jasper, S. (1977). Use of Nuclepore filters for counting bacteria by fluorescence microscopy Appl. environ. Microbiol. 33: 1225-1228

Joint, I. R., Pomroy, A. J. (1987). Activity of heterotrophic bacteria in the euphotic zone of the Celtic Sea. Mar. Ecol Prog. Ser. 41: 155-165

Joint, I., Pomroy, A. (1993). Phytoplankton biomass and production in the southern North Sea. Mar. Ecol. Prog. Ser 99: 169-182

Lee, S., Fuhrman, J. A. (1987). Relationships between biovolume and biomass of naturally derived marine bacterioplankton. Appl. environ. Microbiol. 53: 1298-1303

Malone, T C., Ducklow, H. W. (1990). Microbial biomass in the coastal plume of Chesapeake Bay: phytoplanktonbacterioplankton relationships. Limnol. Oceanogr. 35 296-312

Nagata, T. (1986). Carbon and nitrogen content of natural planktonic bacteria. Appl. environ. Microbiol. 52: 28-32

Nagata, T., Watanabe, Y (1990). Carbon- and nitrogen-tovolume ratio of bacterioplankton grown under different nutritional conditions. Appl. environ. Microbiol. 56: 1303-1309

Psenner, R. (1990). From image analysis to chemical analysis of bacteria: a long-term study? Limnol. Oceanogr. 35: $234-237$

Stramski, D. (1990). Artifacts in measuring absorption spectra of phytoplankton collected on a filter. Limnol. Oceanogr. 35: $1804-1809$

Suzuki, M. T., Sherr, E. B., Sherr, B. F. (1993). DAPI direct counting underestimates bacterial abundances and average cell size compared to AO direct counting Limnol. Oceanogr. 38: 1566-1570

Taguchi, S., Laws, E. A. (1988). On the micro-particles which pass through glass-fiber filter type GF/F in coastal and open waters. J. Plankton Res. 10: 999-1008

Manuscnpt first received: May 19, 1994

Revised version accepted: October 11, 1994 